УДК 323.1 (477) “1918/1919”

\title{
ВЗАСМИНИ ГУЦУЛЬСЬКОЇ РЕСПУБЛІКИ ІЗ ЗАХІДНОУКРАЇНСЬКОЮ НАРОДНОЮ РЕСПУБЛІКОЮ
}

\author{
Микола МУШИНКА \\ Асочіачія украӥнців у Словаччині \\ вул. Горького, 21, 08001, Пряшів, Словаччина \\ e-mail:mykola.musinka@gmail.com \\ DOI: $10.15330 /$ gal.32.104-112 \\ ORCID: 0000-0002-8598-9019
}

9 січня 1919 р. на багатотисячному вічі у селі Ясіня на Закарпатті була обрана 42 -членна Українська Народна Рада із 12 -членною Головною Управою, яка проголосила Гуиульську Республіку як самостійну державу. У периі дні Гуиульська Республіка зав'язала стосунки із Західноукраїнською Народною Республікою (далі ЗУНР), прохаючи від неї військової допомоги. Неофіційна допомога у формі 23 старшин ЗУНР надійшла 18 січня 1919 р. під час походу війська Гуцульської Республіки (Національної Оборони) на Мараморошський Ситіт, де воно зазнало поразки з боку румунської армії. 3 квітня 1919 р. при ЗУНР у Станиславові існувало постійне представництво Украйнськоӥ Центральної Ради в Хусті. У червні 1919 р. Гуцульська Республіка була ліквідована румунською армією, а ї̈ представники, разом зі С. Клочураком арештовані у Брашеві. У вересні 1919 р. Дипломатична місія ЗУНР визволила гуиулів із тюрми і створила на їх основі Гуиульську сотню ЗУНР на чолі зі С. Клочураком, яка брала участь у кількох військових операціях ЗУНР, а після поразки ЗУНР залишки сотні опинилися у Чехословаччині.

Ключові слова: Гуиульська Республіка, Степан Клочурак, Західноукраӥнська Народна Республіка, Злука з Українською Народною Републікою.

Гуцульська Республіка, як територіально-державне утворення на Закарпатті була проголошена 9 січня 1919 року в с. Ясіня, нинішнього Рахівського району, на багатотисячному вічі щойно заснованою 42-членною Українською Народною Радою та іiі 12-членною Головною Управою. Від самого початку вона утримувала зв'язки із Західноукраїнською Народною Республікою. На жаль, в Україні та українській діаспорі Гуцульська Республіка є маловідомою ${ }^{1}$ науковою проблемою.

Уродженець села Чорна Тиса біля Ясіня Степан Клочурак (1895-1980) був офіцером Австро-Угорської армії, а після поранення на фронті Першої світової війни лікувався у Празі, де був свідком проголошення Чехословацької Республіки 28 жовтня 1918 р. ${ }^{2}$. Після повернення додому 4 листопада 1918 р. в Ясіня він очолив 80-членну народну міліцію (із числа демобілізованих місцевих вояків Австро-угорської армії), яка у той день роззброїла місцеву жандармерію та мадярську поліцію і взяла владу у свої руки, збільшивши кількість членів міліції ("Національної оборони") на 200 чоловік.

8 листопада 1918 р. С. Клочурак скликав на центральній площі Ясіня багатолюдне віче (близько семи тисяч чоловік). Учасники віча, за зразком Чехословаччини, проголосували за вихід Закарпаття зі складу Угорщини і його приєднання до України ${ }^{3}$. Там же було обрано 42членну Українську Народну Раду на чолі зі Степаном Клочураком, яка на першому засідан- ні, 9 листопада 1918 р., обрала 12-членну Головну Управу ГР. Вона, своєю чергою, обрала двочленну делегацію (Степана Клочурака та Івана Климпуша), доручивши ій якнайшвидше

\footnotetext{
${ }^{1}$ Верига В. Визвольні змагання в Україні. 1914-1923. Львів, 1998. Т. 1. 263 с. ; Гренджа-Донський В. Назустріч волі : Збірка оповідань з часів революції з рp. 1918-1919. Ужгород, 1930 ; Дудикевич О. Гуцули за соборну Україну. Нова Свобода. 1939. 1 січня. Ч. 1. С. 5 ; Сливка Ю. Гуцульська республіка. Енииклопедія Сучасної Украӥни. Київ, 2006. Т. 6. С. 696.

${ }_{2}^{2}$ Мушинка М. Лицар волі. Життя і політична діяльність Степана Клочурака. Ужгород, 1995. 284 с. ; Друге доповнене видання. Ужгород, 2011. С. 34.

${ }^{3}$ Клочурак С. До волі. Передмова “До волі з вінком терновим” М. Мушинка. Ужгород, 2009. С. 96-106.
} 
виїхати у тодішню столицю ЗУНР м. Станиславів і передати їй Резолюцію Головної Управи ГР про вихід Закарпаття (“Угорської Русі”) зі складу Угорщини і з'єднання з ЗУНР. Делегація виїхала в Станиславів і була прийнята тодішнім прем'єр-міністром ЗУНР Сидором Голубовичем, якого було поінформовано про події на Закарпатті. Гуцули невдовзі таємно повідомили Голубовича про підготовку повстання Національної оборони ГР в Ясіня проти загону Угорської армії і попросили залучення до повстання кількох сотень вояків війська ЗУНР Української Галицької Армії. С. Голубович привітав резолюцію, однак щодо військової допомоги повстанню роз'яснив, що з огляду на несприятливу ситуацію на польсько-українському фронті не зможе надати гуцулам військової допомоги. Цю справу, на його думку, спочатку потрібно належно апробувати не лише на території Закарпаття, але й усієї України та Європи. За пропозицією С. Голубовича при уряді ЗУНР було створено спеціальну Секцію пропаганди для угро-русинів, яка мала постачати на Закарпаття українську літературу та шкільні підручники. До складу Секції від Гуцульської Республіки увійшов, зокрема, С. Клочурак.

Посланці Закарпаття відвідали редакцію часопису "Нове життя", очолювану Костем Кисілевським, видавництво та інші установи. До Ясіня вони повернулися з кількома сотнями українських шкільних підручників, які стали першою лектурою місцевих дітей. Привезли також багато українських газет, журналів та пропагандистської літератури.

За зразком ясінської Української Народної Ради було засновано аналогічні ради майже в усіх селах закарпатської Гуцульщини, а також у Мараморошському Сиготі, Ізі, Бедевлі, Дубовому та ін. Всі вони підтримували ідею приєднання Закарпаття до України.

Уряд Угорщини налякався такого масового антиугорського зриву $\mathrm{i}$, щоб утримати Закарпаття у складі Угорщини, створив у Будапешті проугорську Русску Народну Раду, яка скликала на 10 грудня 1918 р. до Будапешта з’їзд делегатів із цілого Закарпаття. Священика Ореста Сабова було іменовано міністром для справ русинів в Кабінеті прем'єра Каролія. Саме Сабову прем'єр доручив опрацювати проект автономії для Закарпаття, який мав бути обговорений $\mathrm{i}$ ухвалений на з'їзді. У будапештському з'їзді взяло участь близько 500 делегатів. Згідно із задумом угорського уряду вони мали ухвалити проект “вічного" співжиття русинів у “братньому союзі” з угорцями. 3 делегатами із Закарпаття у Будапешт було відправлено, зокема, спеціальний поїзд.

Ідея автономії Закарпаття в рамках Угорщини на будапештському з'їзді мала своїх палких прихильників, зокрема в колах змадяризованої інтелігенції західного Закарпаття. Коли вже здавалося, що ця ідея переможе, на трибуну вийшов С. Клочурак i, зокрема, заявив: “Наші недавні опікуни надіються, що наш народ настільки неграмотний і несвідомий, що знову натягне ярмо на свою шию. Вони грубо помиляються. Вони забули, що нас, наших батьків i братів, національно усвідомлювали вони самі в своїх тюрмах, або коли нас загнали дивитися, як вішають наших батьків і братів на “братські” шибениці. Така “братська" школа научила нас свій народ любити і ненавидіти його гнобителів та дала нам відвагу боротись за права і свободу нашого народу. Така “братська" школа скерувала нас на шлях, яким ідучи, ми виведемо наш народ $з$ тисячолітньої неволі. Хто з нас любить свій народ, його своєрідну культуру, його звичаї й віру та хоче йому до кінця життя вірно служити і не хоче його запродати, той повинен це місце $з$ огидою покинути. Ми повинні доказати, що ми не є неграмотне послушне стадо, але гідні сини свого народу"4.

На будапештському з'їзді остаточно провалилася ідея автономії Закарпаття в складі Угорщини. Національно свідомі делегати вимагали скликання всенародного з'їзду на рідній землі, який би вирішив питання подальшої долі русинів на Закарпатті.

3’їзд делегатів Мараморошської жупи, відбувся у Сиготі 18 грудня 1918 р. На ньому було засновано Мараморошську Руську (Українську) Народну Раду (голова - Юліян Бращайко, заступник - Августин Штефан). Членом проводу Ради став і Степан Клочурак. Саме йому було доручено важливе завдання - утримувати зв'язки Ради з Урядом ЗУНР у Станиславові. Кожний новообраний член Ради складав урочисту присягу відданості українському народові. С. Клочурак у промові на з'їзді поінформував присутніх про свій візит до прем’єра ЗУНР С. Голубовича та

\footnotetext{
${ }^{4}$ Клочурак С. До волі (Спомини) / передмова В. Шандора. Нью-Йорк, 1978. С. 103-104.
} 
про заснування при уряді ЗУНР у Станиславові секції пропаганди для угро-русинів. Дату скликання Хустського з'їзду - “Загального собору всіх русинів, живучих в Угорщині” було призначено на 21 січня 1919 р.

2 січня 1919 р. у Станиславові відбулося урочисте засідання Народної Ради Західної України, на якому було проголошено об'єднання Західно-Української Народної Республіки з Українською Народною Республікою, тобто злуку Західної і Східної України. У засіданні, яке було відкрито гімном “Ще не вмерла Україна”, брала участь і тричленна делегація закарпатських українців (С. Клочурак, Є. Пуза та I. Климпуш). Делегатом від Пряшівщини на станиславівському зїзді був Яцко Остапчук із Радвані-на-Лабірці. Він поінформував делегатів про зїзд русинів-україн- ців у м. Стара Любовня 8 листопада 1918 р., на якому було засновано Руську Народну Раду, яка прийняла резолюцію про приєднання "Угорської Русі" до України. 2 січня 1919 р. делегація угорських русинів відвідала Голову ЗУНР Свгена Петрушевича та державного секретаря Народної оборони ЗУНР Дмитра Вітовського, та поінформувала їх про останні події на Закарпатті. I на цей раз закарпатці від уряду ЗУНР майже жодних обіцянок щодо військової допомоги не одержали у зв'язку зі складною міжнародною ситуацією та польсько-українською війною. I Петрушевич і Вітовський радили закарпатцям взяти владу від угорців у свої руки хоча би в одному невеличкому районі, з якого визволення з-під чужого ярма поступово поширилося б на все Закарпаття. Для такої операції ЗУНР була готова таємно направити на Закарпаття невеличкий контингент своїх вояків, головним чином старшин, нібито добровольців, що прибули туди без відома уряду ЗУНР. Їхня кількість не була встановлена. Делегація погодилася з таким планом і навіть визначила термін початку повстання в Ясіня на Різдвяну ніч - із 6 на 7 січня 1919 p. $^{5}$.

Повернувшись у Ясіня, делегація 5 січня 1919 р. на таємній нараді інформувала членів управи Ради про переговори у Станиславові. Всі без винятку погодилися з рішенням підняти повстання в Ясіня. Уряд Угорщини уважно стежив за подіями на Закарпатті, зокрема на Гуцульщині, де антиугорські прояви були найбільш інтенсивні. Ще наприкінці грудня 1918 p. до Ясіня було направлено із Будапешта 620-членну каральну експедицію. Угорські солдати поводили себе в Ясіня вкрай агресивно - скасували Руську (Українську) Народну Раду, роззброїли народну міліцію, всі посади місцевої управи замінили колишніми угорськими урядовцями, запровадили угорську мову у школі та в усіх установах, жорстоко переслідували будь-який прояв українського національного почуття. Щоправда, арештувати провідників українського руху вони за тих обставин не наважилися ${ }^{6}$.

Степан Клочурак з чільними представниками Ради - братами Климпушами, Дмитром Німчуком, Михайлом Сабадюком та своїм батьком Степаном вирішили підняти повстання проти окупаційних угорських військ і згідно з ухваленим планом здійснити переворот державної влади в Ясіня.

Під час різдвяної коляди 6-7 січня 1919 р. він разом із своїми однодумцями таємно зібрав 86 озброєних гуцулів - членів роззброєної Гуцульської Національної Оборони, до яких долучилося 23 старшини та вояки Української Галицької Армії, що таємно прибули з Коломиї, i в ту ж ніч 109-членний загін повстанців, очолюваний С. Клочураком, без людських жертв роззброїв 620 угорських солдат (разом із командиром-полковником та чотирма офіцерами). Крім того було захоплено прикордонну поліцію, залізничну станцію, пошту і всі установи в селі. Тож, гуцули знову стали господарями у своєму краї.

У ході військової операції гуцули, обірвавши телефонне сполучення угорських військових частин між собою та 3 центром у Рахові, повстанці кожній частині заявили угорською мовою: "Ви є оточені багаточисленною українською армією, яка знаходиться в навколишніх лісах. Здайтеся добровільно, бо не маєте найменшої надії на перемогу! Якщо здасьте зброю, нікому з вас нічого не станеться. Повернетеся додому. Як ні - загинете!”. А знадвору і справді було чути гамір, стрільбу, немов там $є$ принаймні дивізія вояків. Таким чином, до рук по-

\footnotetext{
${ }^{5}$ Клочурак С. До волі (Спомини)... С. 122-125.

${ }^{6}$ Мушинка М. Лицар волі. Життя і політична діяльність Степана Клочурака. Ужгород, 1995. 284 с. ; Друге доповнене видання. Ужгород, 2011. С. 46.
} 
встанців потрапляла частина за частиною з повними арсеналами зброї та амуніції. Протягом однієї ночі всі угорські солдати а також прикордонна сторожа були роззброєні, а вся їх зброя опинилися в руках повстанців. Чималу роль в успіху гуцульського повстання зіграли і галицькі старшини, хоча вони прибули в мінімальній кількості - усього 23 чоловік ${ }^{7}$.

Наступного дня, 8 січня 1919 р. в повному складі зійшлася розпущена угорцями Українська Народна Рада в Ясіня, яка проголосила самостійну і незалежну Гуцульську Республіку. Їі законодавчим і виконавчим органом стала Українська Народна Рада, очолювана С. Клочураком. Рада обрала його на посаду президента Гуцульської Республіки та провідника секції військових справ і зовнішніх зв'язків. У новоствореній республіці С. Клочураку вдалося налагодити зразкову дисципліну - iї військо вже у перші дні збільшилося на 424 чол., із яких 109 були добровольцями 3 Галичини. Всіх полонених угорців упродовж шести днів було відправлено в Угорщину невеликими групами. Невдовзі на всі посади державної адміністрації повернулися місцеві люди, а українська мова набула статусу офіційної. Нею користувалися не лише у школі чи установах, але й у військових частинах. Про результати повстання у Ясіня та проголошення Гуцульської Республіки посередництвом кур'єрів було негайно інформовано і уряд ЗУНР.

Вже 10 січня 1919 р. Українська Народна Рада в Ясіня опублікувала звернення до русинів Закарпаття, в якому, посилаючись на принципи американського президента Вільсона про самовизначення народів, закликала усіх закарпатських русинів до збройного повстання проти угорських окупантів.

Звернення закінчилися закликом: “Брати рідні! Всі, що здібні під оруж’є, ставайте в ряди добровільців у своїй військовій одежі і обуві та принесіть зі собою всяке оруж'є і муніцію. Організуйте добровільні відділи та бороніть Вашої волі і рідної землі. Наші закарпатські (галицькі й східноукраїнські. - M. М.) брати нам допоможуть, але наше діло є вибороти свободу і закріпити їі! (підкреслено в оригіналі. - М. М.) Тож до зброї, брати! До організації своїх сил! Бо лише тоді, як буде у нас сильне і здисципліноване військо, то наші гнобителі не вдіють нічого проти нас. [...] Най живе один великий український народ від Тиси аж по Чорне море i гори Кавказ! Най живе і пишається наша велика одноцільна Українська Республіка!”».

Це звернення було розповсюджене не тільки по селах Мармарощини, але також у Свалявщині та Веречанщині. Дмитро Німчук, який виконував функцію кур'єра між Гуцульською Республікою і ЗУНР, поніс звернення до Хусту, а звідти воно потрапило на Угочанщину.

Зазначимо, що на Марамарощину зазіхала і Румунія, війська якої вже 11 листопада 1918 p. захопили столицю Буковини - Чернівці і просувалися надалі на захід. Українська Народна Рада в Ясіня вже у перші дні своєї перемоги одержали вістку, що румунська армія поступає у Мараморощину з метою зайняти іiї столицю - місто Мараморошський Сигіт.

Аби запобігти окупації Сигота румунами, Українська Народна Рада в Ясіня, окрилена успіхом свого повстання, вирішила направити у Сигіт своє військо, кількість якого в короткому часі збільшилася до 800 чоловік.

13 січня 1919 р. три вповні укомплектовані сотні війська Гуцульської Республіки, поповнені новоприбулими стрільцями - старшинами й підстаршинами УГА, вирушили окремим поїздом на Мараморошський Сигіт. Четверта, запасна сотня залишилася для охорони Ясіня. Порівняно легко вони зайняли Кваси, Білин та Рахів, роззброївши угорські відділи в цих місцевостях. Перед Мараморошським Сиготом військо Гуцульської Республіки нараховувало близько 1100 вояків, з яких майже половину становили галицькі українці, що ніби “без відома уряду Західної України" прибули на допомогу закарпатцям.

Гуцульське військо майже без опору зайняло Сигіт, роззброївши угорські військові частини. У військових казармах Сигота гуцули захопили велику кількість гарматних патронів, дрібної амуніції, ручних гранат та інших вибухових матеріалів, а також значний запас харчів, головним чином, цілі пакунки консервів. Наступного дня прибули до Сигота свіжі поповнення УГА із Коломиї.

\footnotetext{
${ }^{7}$ Клочурак С. До волі. Передмова “До волі з вінком терновим” М. Мушинка... С. 126-128.

${ }^{8}$ Там само. С. $138-139$.
} 
Місцева влада, складена з румунів, мадяр і євреїв, вислала до румунського командування кілька прохань захистити місто перед “рабунками гуцульських більшовицьких бандитів", а в ніч 316 на 17 січня 1919 р. вислала у Велику Баню, де був розташований румунський гарнізон, 50 возів, аби привезти в місто регулярне румунське військо. У результаті цих військових заходів у Сигіт прибуло біля 2000 румунських вояків з кулеметами та гарматами.

Невдовзі Сигіт оточила добре озброєна румунська армія. Гуцулам та стрільцям УГА було зрозуміло, що в них немає можливості перемогти румунів, і вони вступили у переговори 3 ними, а коли ці переговори виявилися безрезультатними, вирішили без бою залишити Сигіт i відступити до Бичкова. Однак у Сигітській Коморі гуцульські загони потрапили у румунську пастку і зазнали поразки - 18 гуцульських вояків було вбито, 39 поранено, а велика частина потрапила у полон.

У результаті цих заходів уряд Західної України наказав окружній команді в Коломиї негайно відкликати свої відділи із Закарпаття, не бажаючи вступати у конфлікт із Румунією та Угорщиною. Цей наказ було виконано, і Гуцульська Республіка знову була вимушена оператися лише на власні сили.

Румунські переможці поводилися зі своїми жертвами надзвичайно суворо: “Мертвих та ранених без милосердя ограбили зі всіх пригожих предметів. Не поводилися краще ні з живими та здоровими полоненими. Всіх їх зігнали румуни на вкриту снігом луку перед станцією, обложили їх довкруги кулеметами, готовими кожної хвилини до стрілу так, щоб вони не втікали. 3 приходом кожного свіжого транспорту полонених вітали диким криком, кидалися на них, били їх кулаками та прикладами рушниць, копали їх та не забували при тому ограбити 3 усього того, що представляло будь-яку вартість", .

Після побиття і пограбування полонених одразу ж повезли до Сиготу, де їх запроторили до кількох пивниць, здорових і поранених разом. Там їх довго морили голодом і знову знущалися над ними.

“Так трагічно закінчився наш похід на Сигіт”, - писав С. Клочурак у своїх спогадах ${ }^{10}$. Сам він, щоправда, у поході безпосередньої участі не брав, бо саме тоді у Рахові організовував нові загони гуцульської оборони.

Після поразки в Сигітській Коморі залишки гуцульського війська відступили до Ясіня. Румуни їх не переслідували, однак нападали на них мадярські терористичні групи, завдаючи подальших людських втрат. У Ясіня С. Клочурак сформував нове військо. Гуцульська Республіка не припинила свого існування і після сигітської поразки, Українська Народна Рада в Ясіня продовжувала свою діяльність. Усі дороги до Ясіня були під контролем місцевої міліції, яка, крім гуцулів, нікого в село не пускала.

Всенародний з'їзд делегатів Угорської Русі у Хусті відбувся у раніше встановлений термін - 21 січня 1919 р. У заході взяло участь кілька сотень делегатів із всіх районів Закарпаття, включно з Пряшівщиною. Невдалий похід на Сигіт був найчастіше обговорюваною темою в кулуарах з'їзду. Утім, поразка не відрадила делегатів від боротьби за приєднання Закарпаття до України. У резолюції з'їзду, зокрема, $є$ і такий пункт: “1. Всенародні збори угорських русинівукраїнців 3 дня 21 януара 1919 р. висказують з'єднання всіх русинів-українців з комітатів: Мармарош, Угоча, Берег, Унг, Земплін, Шариш, Спиш, Абуй-Торня і прилучення русинами-українцями заселених земель до соборної України, просячи, щоби нова Держава при виконуванню сеї злуки узгляднила особливе положення угорських русинів-українців. Для того всенародні збори заявляють, що руський народ Угорщини Десятий закон про Руську Крайну, даний в Будапешті в року 1918, не признає законом, бо повстав без його волі і без заступництва народу [...]"11.

\footnotetext{
${ }^{9}$ Кудей 3. Гуцульська Республіка / авторизований український переклад Юрія Роїка. Львів, 1937. Т. 1. С. 77-78.

${ }^{10}$ Клочурак С. До волі.. С.143.

${ }^{11}$ Мушинка М. Лицар волі. Життя і політична діяльність Степана Клочурака. Ужгород, 1995. 284 с. ; Друге доповнене видання. Ужгород, 2011. С. 59.
} 
На з'їзді, який закінчився гімном “Ще не вмерла Україна”, було засновано 100-членну Руську (Українську) Центральну Раду (РУЦНР), на чолі з Михайлом Бращайком. До її складу увійшов, зокрема, і С. Клочурак. Отже, на Хустському з'їзді черговий раз пролунала ідея возз'єднання закарпатських земель з Україною. На жаль, політичні події наступних днів і місяців не дозволили на практиці реалізувати це возз'єднання.

На початку квітня 1919 р. С. Клочурак разом з С. Пузою за дорученням Русько-Української Центральної Народної Ради в Хусті знову відвідали прем'єра ЗУНР Сидора Голубовича та міністра військових справ Дмитра Вітовського з проханням надати Гуцульській Республіці економічну й військову допомогу. Утім, у військовій допомозі їм і на цей раз було відмовлено $з$ огляду на несприятливу міжнародну ситуацію. Зате обоє вони погодились, щоб у Станиславові було постійне представництво Русько-Української Центральної Ради в Хусті. Першим представником Закарпаття (“Угро-України”) при уряді Західно-Української Народної Республіки у Станиславові голова Хустської Ради Михайло Бращайко призначив Степана Клочурака. Він залишився, зокрема, жити у Станиславові ${ }^{12}$. У Підволочиську він особисто зустрічався 3 отаманом Симоном Петлюрою. Вислухавши його скаргу на поганий стан з харчами, Петлюра вислав до Ясіня як дар Українській Народній Республіці кілька вагонів хлібної муки в білих мішках з написом "Україна". Ці мішки з добротного білого полотна селяни довго зберігали як цінні сувеніри.

Крім того, допомога з України мала не лише економічне, а й велике моральне значення. Для відновлення війною знищених будинків громадяни безплатно одержували дерево, було налагоджене залізничне сполучення між Раховом і Ясіня та між Ясіня, Станиславовом та Коломиєю. У школах відновилося навчання, інваліди й пенсіонери щомісячно одержували пенсії.

Між тим, у першій половині 1919 р. політична ситуація на Закарпатті значно ускладнилася. Східну частину Закарпаття аж до Берегово зайняли румуни, центральну з Мукачевом угорці, а західну, з Ужанською долиною - чехи. Певним острівцем свободи і незалежності залишилася Гуцульська Республіка з центром у Ясіня. За такої ситуації 7 травня 1919 р. у Станиславові відбувся з'їзд гуцулів Закарпаття, в якому взяло участь 132 делегати із 62 громад ${ }^{13}$.

По дорозі на з'їзд С. Клочурак важко захворів тифом, який у тому часі на Гуцульщині значно поширився. У важко хворому стані, з високою температурою він вийшов на трибуну, щоб виголосити промову. Його привітали бурхливими оплесками як українського національного героя, який в неймовірно важких умовах тримає на Закарпатті прапор незалежності. 3 останніх сил він виголосив свою промову, а закінчивши піi, раптово втратив свідомість і впав. Безпосередньо з трибуни його відвезли до лікарні, де він у важкому стані пролежав аж до окупації Станиславова польськими військами.

Разом з тим, з’їзд продовжував роботу без С. Клочурака. На з'їзді було ухвалено резолюцію з вимогою “щоб представники України на Мировій конференції в Парижі домагалися, аби територія Мадярщини, заселена русинами-українцями, була приєднана до України"14. Резолюцію з'їзду було доручено реалізувати голові ЗУНР С. Петрушевичу, який обіцяв посприяти аби справа Закарпаття була порушена на Мирній конференції в Парижі.

Ясінську Гуцульську Республіку невдовзі окупували румунські війська. Гуцульська самооборона, вважаючи оборону безнадійною, не ставила їм опору. Гуцули склали зброю і передали румунам рештки військового майна. Між тим, до Ясіня дійшла вістка, що 8 травня 1919 р. три Народні Ради - Ужгородська, Пряшівська і Хустська погодилися з тим, щоб територія Закарпаття увійшла до складу Чехословаччини, поки на міжнародному форумі не буде вирішена справа України.

Одержавши таке повідомлення, С. Клочурак скликав таємне засідання Головної управи Гуцульської Републіки, на якому Управа визнала, що кращого виходу зі складного політичного становища ніж приєднання Закарпаття до Чехословаччини немає. С. Клочураку було доручено

\footnotetext{
${ }^{12}$ Мушинка М. Лицар волі. Життя і політична діяльність Степана Клочурака. Ужгород, 1995. 284 с. ; Друге доповнене видання. Ужгород, 2011. С. 62-63.

${ }^{13}$ Клочурак С. До волі... С.157.

${ }^{14}$ Там само. С. 164.
} 


\section{0}

опрацювати відповідний меморандум. Він і справді написав текст меморандуму, згідно з яким Українська Народна Рада в Ясіня звертається до Центральної Руської Народної Ради в Ужгороді з проханням, аби остання вжила заходів, щоб найсхідніша частина Закарпаття - Мараморощина була звільнена від румунської окупації і разом з іншими закарпатськими землями приєднана до Чехословаччини. Меморандум підписало, зрештою, п'ятнадцять членів Ясінської УНР. 11 червня 1919 р. посередництвом Є. Пузи та Д. Німчука цей меморандум було передано Ужгородській Раді, а згодом - Президентові ЧСР Т. Г. Масарику ${ }^{15}$.

До слова, в той же день, 11 червня 1919 р. із Сигіта до Ясіня прибув спеціальний румунський військовий загін, щоб дослідити скаргу угорських та єврейських мешканців села на Українську Народну Раду як терористичну банду, члени якої нібито протягом півроку допустилися численних кримінальних злочинів і заслуговують покарання.

Наступного дня розпочалися масові арешти членів Ради. Першими було арештовано i вивезено до сигітської в'язниці ватажка “банди” - Степана Клочурака. Згодом румуни арештували майже всіх членів Ради, яких удалося спіймати. Причому били та морили голодом не лише їх, а й членів їхніх родин. Утім, судове слідство не встановило жодних злочинів арештованих за винятком С. Клочурака. Їх було невдовзі звільнено 3-під арешту і навіть збережено на попередніх посадах у селі. Разом із тим, С. Клочурака як організатора озброєного походу на Мароморошський Сигіт, під час якого було вбито вісім румунських вояків, було поставлено перед румунським військовим судом. Йому загрожувала кара смерті, однак перед судом він блискуче захищав себе, у зв'язку з чим отримав найнижчу міру покарання - шість місяців ув'язнення. Кару відбував у сумнозвісній твердині м. Брашова, де зустрівся зі своїми земляками, що потрапили свого часу у полон у Сигітській Коморі. Після трьох місяців Українська дипломатична місія в Бухаресті визволила його разом із земляками із в'язниці ${ }^{16}$.

Наприкінці вересня 1919 р. у передмісті Бухареста Котрочень, сформувалася міцна сотня із закарпатців, переважно гуцулів, що потрапили у румунський полон після поразки в Сигітській Коморі. Голова Української надзвичайної комісії в Румунії генерал Сергій Дельвіг (1866-1944) командиром сотні призначив якраз Степана Клочурака.

Сотня С. Клочурака увійшла до складу так званого “Румунського куреня" Української Галицької Армії, яким командував сотник Микола Саєвич (1885-1944). На початку жовтня 1919 р. сотню було перекинуто в Могилів, де вона була переозброєна і в рамках куреня вислана у Вінницю на бій з більшовиками і денікінцями. Першу бойову операцію закарпатська сотня здійснила в Проскурові (нині Хмельницький), ліквідувавши більшовицький загін, який роззброїв місцеву міліцію і намагався підняти повстання проти Директорії Української Народної Республіки.

3 Вінниці курінь Саєвича разом із сотнею Клочурака по наказу Директорії УНР та уряду ЗУНР переведено до Кам'янця-Подільського. Куреню було доручено почесне завдання - охороняти Директорію, очолювану отаманом С. Петлюрою та уряд Західно-Української Народної Республіки на чолі з Президентом Свгеном Петрушевичем.

Служба в Кам’янці-Подільському не була легкою, оскільки в місті панувала анархія, яка охоплювала й армію. Одночасно у місті лютував тиф і невдовзі десять воїнів закарпатської сотні С. Клочурака захворіло. Так, на початку 1939 р. у статті "Гуцули за соборну Україну" описав участь закарпатців в українському соборному війську Осип Дудикевич: “Коли ж на губерніальній площі в Кам'янці на Поділлі дня 1 листопада 1919 року віддавали стрільці честь упавшим і святили відродження між частинами Галицької Армії, твердим кроком маширували гуцули 3 т. зв. румунського куріня. А були там знов Клемпуші, Клочурак і інші друзі, що по пропущенні із румунської неволі перейшли Дністер і зголосилися в ряди Української Соборної Армії, не боячися тифів, нужди, щоб дальше боротися за Україну. Честь борцям, що чесно за неї воювали" 17 .

\footnotetext{
${ }^{15}$ Мушинка М. Лицар волі. Життя і політична діяльність Степана Клочурака. Ужгород, 1995. 284 с. ; Друге доповнене видання. Ужгород, 2011. С. 64-65.

${ }^{16}$ Клочурак С. До волі... С. 160-165

${ }^{17}$ Дудикевич О. Гуцули за соборну Україну. Нова Свобода. 1939. Ч. 1. 1 січня. С. 5.
} 
Однак, закарпатцям після цього параду вже не довелося воювати за Соборну Україну. С. Клочурак вирішив зберегти сотню як одне ціле і через Польщу дістатися на територію Чехословаччини. Це аж ніяк не була легка справа, оскільки Польща на той час перебувала у воєнному конфлікті з Україною, а його частина була складовою частиною Української Галицької Армії.

16 листопада 1919 р. 126 воїнів сотні під командуванням С. Клочурака вирушили із Кам'янця-Подільського до польського кордону і під вечір наступного дня біля села Мельниця дісталися через ріку Збруч на територію Польщі, де сотню невдовзі заарештували. Після тижневого ув'язнення у чортківській тюрмі та інтенсивних допитів їх як полонених австрійськоугорської армії відвезли до Станиславова і передали репатріаційній комісії, яка видала їм відповідні документи для повернення додому.

Закарпатська Гуцульщина на той час була окупована румунськими військами і повертатися туди воїнам колишньої Гуцульської Республіки було небезпечно. Та, незважаючи на небезпеку, основна частина сотні С. Клочурака вирушила через Делятин до Ясіня, однак Степан із сімнадцятьма стрільцями, вирішили не ризикувати, а через Львів і Краків подалися у Моравію. 23 листопада 1919 р. в місті Богуміні поляки передали залишки Гуцульської сотні чехословацькій військовій команді.

Того самого дня всю групу було відправлено у Ліпник-над-Бечвою, де закарпатським хлопцям довелося відбути тритижневий карантин. 7 грудня 1919 р. С. Клочурак склав присягу на вірність Чехо-Словаччині і його того ж дня як офіцера чехословацької армії було відправлено до Мукачева 3 наданням 14-денної відпустки. По дорозі додому він відвідав Українську Військову Місію в Кошицях, де одержав найновішу інформацію про події на Наддніпрянській Україні ${ }^{18}$.

8 грудня 1919 р. Степан Клочурак прибув до Ужгорода, а звідти, у рідне Ясіня, яке щойно звільнилося від румунської окупації. Там його привітали не лише батьки, брати й сестри, але й численні побратими по зброї та колишні члени Української Народної Ради - парламенту Гуцульської Республіки.

С. Клочурака просили залишитися в Ясіня, пропонували місце сільського старости, начальника пограничної поліції та навіть посаду нотаря. Але він хотів працювати не лише для Гуцульщини, а й для цілого Закарпаття, тому після двотижневої відпустки зголосився у військовій комендатурі до Чехословацької армії в Мукачево, i, демобілізувавшись, виїхав до Ужгорода, де розгорнув широку політично-громадську діяльність ${ }^{19}$.

Упродовж 1920-30-х рр. С. Клочурак проживав в Ужгороді - був співзасновником “Просвіти”, працював у “Січі", "Пласті” та українських економічних товариствах. Був співзасновником та чільним представником Соціал-демократичної партії Підкарпатської Русі (1920-1926 рр.), згодом - “Українського крила” Аграрної партії (1934-1938 рр.). Був головним редактором українських газет “Народ”, “Вперед”, “Земля і Воля” та “Нова Свобода”. В уряді Карпатської України (Августина Волошина) займав посаду міністра господарства, згодом міністра національної оборони. Після поразки Карпатської України у березні 1939 р. С. Клочурак із сім'єю переселився у Прагу, де очолив “Ліквідаційну канцелярію Карпатської України”. У період Другої світової війни С. Клочурак займався підприємницькою діяльністю.

12 травня 1945 р. органи радянської контррозвідувальної організації "СМЕРШ" (“Смерть шпіонам”) арештували у Празі президента Карпатської України Августина Волошина, а через кілька днів і міністрів його уряду Степана Клочурака, Миколу Долиная та Юрія Перевузника. Невдовзі їх усіх спеціальним військовим літаком перевезли у Москву, де помістили до в'язниці, у Лефортово, піддавши суворим допитам. А.Волошин у в'язниці помер від паралічу серця 19 липня 1945 р., а С. Клочурака “Особое совещание НКВД” 26 грудня 1946 р. засудило на вісім років виправно-трудових таборів. Кару він відбув на Воркуті, працюючи шахтарем. Після відбуття повного строку покарання, у травні 1956 р., С. Клочураку зачитали нову постанову про обов'язкове перебування на Воркуті на “невизначений строк”, тобто довічне заслання.

\footnotetext{
${ }^{18}$ Клочурак С. До волі... С. 169-177.

${ }^{19}$ Там само. С. $78-79$.
} 


\title{
112
}

До сім'ї у Прагу він повернувся лише 18 жовтня 1957 р., тобто після дванадцяти 3 половиною років. Додамо, що життя С. Клочурака до 1920 р. детально описано у першому томі його спогадів “До волі”,

Закарпаття вшанувало пам'ять С. Клочурака перевиданням його спогадів “До волі”, двома виданнями монографії про його життя і політично-громадську діяльність “Лицар волі”, а також серією журнальних статей та побудовою пам'ятника в його рідній Ясіня. Утім, його багата спадщина, зокрема публіцистика, ще чекає на свого дослідника.

\section{RECOGNITION OF THE HUTSUL REPUBLIC WITH THE WEST-UKRAINIAN PEOPLE'S REPUBLIC}

\author{
Mykola MUSHYNKA \\ Association of Ukrainians in Slovakia, \\ Gorkého St., 21, 08001, Prešov, Slovakia, \\ e-mail: mykola.musinka@gmail.com
}

\section{Summary}

On January 9, 1919, a 42-member Ukrainian People's Council with a 12-member General Administration was elected at the Yasinia village in Transcarpathia, which proclaimed the Hutsul Republic as an independent state. In the first days, the Hutsul Republic engaged in relations with the Western Ukrainian People's Republic (hereinafter ZUNR), requesting its military assistance. Unofficial assistance in the form of 23 ZUNR leaders was received on January 18, 1919, during a campaign of troops of the Hutsul Republic (National Defense) on Maramoroshsky Sigit, where it was defeated by the Romanian army. From April 1919, there was a permanent representation of the Ukrainian Central Council in Khust at the ZUNR in Stanislavov. In June 1919, the Hutsul Republic was liquidated by the Romanian army, and its representatives, together with S. Klochurak, were arrested in Brasov. In September 1919, the ZUNR Diplomatic Mission released the Hutsuls from prison and based on them a Hutsul hundred ZUNR, led by S. Klochurak, who participated in several ZUNR military operations, and after the defeat of the ZUNR, hundreds remained in Czechoslovakia.

Keywords: Hutsul Republic, Stepan Klochurak, West Ukrainian People's Republic, Union with the Ukrainian People's Republic.

\section{REFERENCE} Ukrainian].

Dudykevych O. Hutsuly za sobornu Ukrainu. Nova Svoboda. 1939. 1 sichnia. CH. 1. S. 5. [in

Grendzha-Donskyi V. Nazustrich voli : Zbirka opovidan z chasiv revoliutsii z rr. 1918-1919. Uzhhorod, 1930. [in Ukrainian].

Klochurak S. Do voli. Peredmova "Do voli z vinkom ternovym” M. Mushynka. Uzhhorod, 2009. S. 13178. [in Ukrainian].

Klochurak S. Do voli (Spomyny) / peredmova V. Shandora. Niu-York, 1978. S. 103-104, 122-125. [in Ukrainian].

Kudei Z. Hutsulska Respublika / avtoryzovanyi ukrainskyi pereklad Yuriia Roika. Lviv, 1937. T. 1.

\section{S. 77-78. [in Ukrainian].}

Mushynka M. Lytsar voli. Zhyttia i politychna diialnist Stepana Klochuraka. Uzhhorod, 1995. 284 s. ;

Druhe dopovnene vydannia. Uzhhorod, 2011. S. 34, 46, 59. 64-65. [in Ukrainian]. Ukrainian].

Slyvka Yu. Hutsulska respublika. Entsyklopediia Suchasnoi Ukrainy. Kyiv, 2006. T. 6. S. 696. [in

Veryha V. Vyzvolni zmahannia v Ukraini. 1914-1923. Lviv, 1998. T. 1. 263 s. [in Ukrainian].

\footnotetext{
${ }^{20}$ Клочурак С. До волі. Передмова “До волі з вінком терновим” М. Мушинка. Ужгород, 2009. С. 13-178.

${ }^{21}$ Мушинка М. Лицар волі. Життя і політична діяльність Степана Клочурака. Ужгород, 1995. С. 85-264.
} 